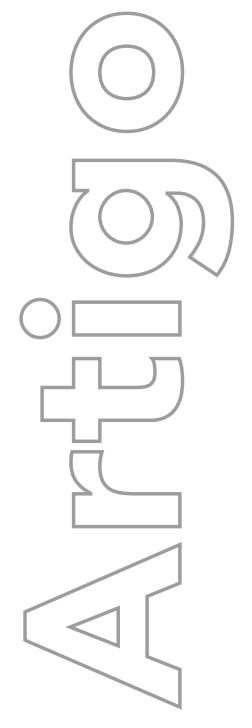

revista

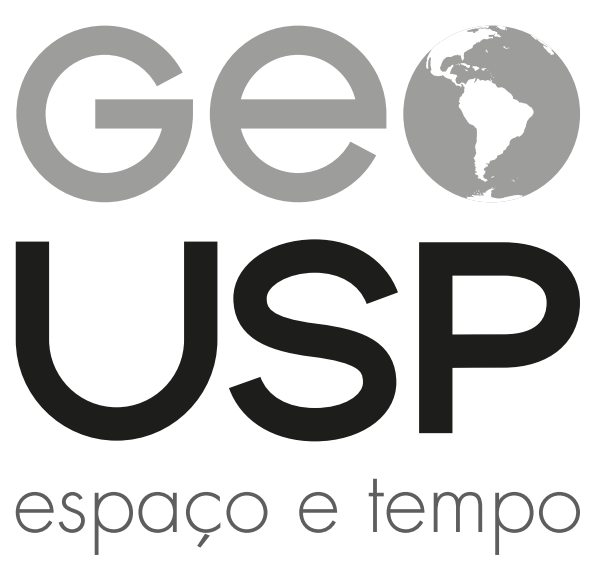

Volume $24 \cdot n^{\circ} 2$ (2020)

ISSN 2179-0892

\section{processo histórico de ocupação e de ocorrência de enchentes na planície fluvial do rio Pinheiros de 1930 até os dias atuais}

Rodolfo Alves da Luz

Universidade Federal do Tocantins, Curso de Geografia e Pós-Graduação em Desenvolvimento

Regional, TO, Brasil e-mail: rodolfodaluz@gmail.com (1) 0000-0002-6608-4898

Cleide Rodrigues Universidade de São Paulo. Faculdade de Filosofia, Letras e Ciências Humanas, SP, Brasil e-mail: cleidrig@gmail.com (1) 0000-0003-4481-7445

p. $340-360$

Como citar este artigo:

LUZ, R. A.; RODRIGUES, C. O processo histórico de ocupação e de ocorrência de enchentes na planície fluvial do rio Pinheiros de 1930 até os dias atuais. Geousp - Espaço e Tempo (On-line), v. 24, n. 2, p. 340-360, ago. 2020. ISSN 2179-0892.

Disponivel em: https://www.revistas.usp.br/geousp/article/ view/164499. doi: https://doi.org/10.11606/issn.2179-0892. geousp.2020.164499.

\section{(c) $\underset{\mathrm{BY}}{\mathrm{BY}}$}

Este artigo está licenciado sob a Creative Commons Attribution 4.0 Licence 


\section{O processo histórico de ocupação e de ocorrência de enchentes na planície fluvial do rio Pinheiros de 1930 até os dias atuais}

\section{Resumo}

O processo de urbanização de São Paulo impôs grandes modificações em seus sistemas fluviais originais, sendo um caso relevante o da planície fluvial e canal do rio Pinheiros. $\bigcirc$ objetivo central deste artigo é aprofundar a caracterização geomorfológica dessas modificações avaliando seu significado para os padrões de ocorrência de inundações e enchentes. Para tanto, usaram-se as ferramentas da geomorfologia antropogênica, principalmente a cartografia geomorfológica retrospectiva, a abordagem histórica e o uso dos geoindicadores. Do ponto de vista das mudanças geomorfológicas, esse processo pode ser sistematizado em três momentos: até a década de 1930, da década de 1930 à de 1990 e da década de 1990 aos dias atuais. Apesar de as enchentes serem um problema constante e resistente na região, projetos que procuram diminuir seus impactos por meio da preservação de setores da planície têm sido sistematicamente ignorados pelos gestores da cidade. Este artigo mostra como a preservação de remanescentes do sistema fluvial e a recuperação das funções hidrológicas perdidas são essenciais para a requalificação urbana, enfatizando a planície fluvial do rio Pinheiros e a necessidade de uma mudança radical na lógica de ocupação e apropriação de planícies fluviais meândricas similares às do rio Pinheiros.

Palavras-chave: Urbanização. Planície fluvial. Enchentes. Rio Pinheiros.

\section{The historical process of occupation and floods on the river Pinheiros fluvial plain from 1930 up to the current days}

\footnotetext{
Abstract

The urbanization process of São Paulo led to large changes in their fluvial systems, as the River Pinheiros fluvial system. This paper purposes enhance the geomorphological
} 
aspects of these transformations, evaluating their meaning in the flood process patterns. For this, anthropogenic geomorphology tools were used, mainly retrospective geomorphological cartography, historical approach and geoindicators. According to their morphological changes, this process can be systematized in three moments: until the 1930s; from 1930s to 1990s; from 1990s to current days. Although floods are a constant problem to the area, projects that sought to reduce their impacts through the preservation of the fluvial plain sectors were, and still are, ignored by the city managers. This paper shows as the preservation of the fluvial systems remaining and the recovering of the lost hydrological functions are essential for the urban regeneration, however, for this, it is necessary a radical change in the logic of the use and appropriation of fluvial plains such as in the River Pinheiros.

Keywords: Urbanization. Fluvial plain. Floods. River Pinheiros.

\section{El proceso histórico de ocupación y ocurrencia de inundaciones en la llanura fluvial del río Pinheiros desde 1930 hasta la actualidad}

\section{Resumen}

El proceso de urbanización de São Paulo impuso grandes cambios en sus sistemas fluviales, como del Río Pinheiros. El objetivo principal es resaltar los aspectos geomorfológicos de estas transformaciones, evaluar su significado en el proceso de inundación. Se utilizaron herramientas de la geomorfologia antropogenica, principalmente la cartografía geomorfológica retrospectiva, el enfoque histórico y los geoindicadores. Desde el punto de vista de los cambios geomorfológicos, este proceso se puede sistematizar en tres momentos: hasta la década de 1930; de la década de 1930 a 1990; de la década de 1990 a los días corrientes. Aunque las inundaciones son un constante problema para la región, los planos que pretendían disminuir sus impactos mediante la preservación de sectores de la llanura fueron, y todavía son, ignorados por los gestores de la ciudad. Este artículo demuestra como la preservación de remanentes del sistema fluvial y la recuperación de las funciones hidrológicas pérdidas son esenciales para la recalificación urbana de la región, sin embargo, es necesario un cambio radical de lógica en el uso y apropiación de llanuras fluviales como la del Pinheiros.

Palabras clave: Urbanización. Llanura fluvial. Inundaciones. Río Pinheiros. 


\section{Introdução}

É reconhecido o fato de que, ao longo da história da humanidade, as cidades se tenham desenvolvido principalmente nos arredores de margens de rios. Mas o que se chama "margem de rio" é, na verdade, um complexo sistema geomorfológico de planície fluvial, composto basicamente por três subsistemas com hidrodinâmica e características próprias: o canal fluvial, a planície de inundação (popularmente conhecida como "várzea") e os terraços fluviais (Leopold; Wolman; Miller, 1964; Tricart, 1966; Christofoletti, 1981; Bridge, 2003) (Figura 1).

\section{Figura 1 - Croqui esquemático de uma planície fluvial}

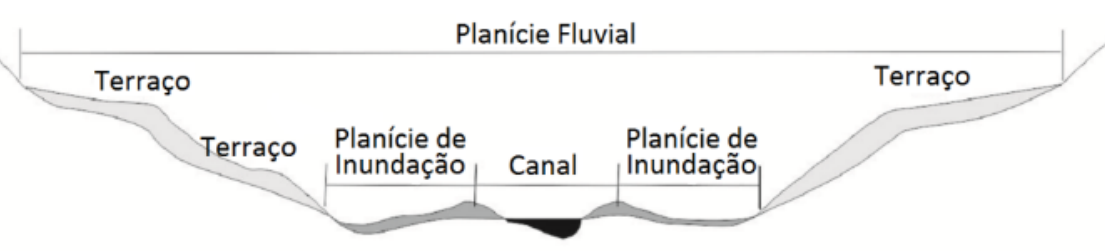

organização: Rodolfo A. da Luz.

De modo geral, as planícies de inundação e os canais fluviais estiveram relativamente livres da ocupação urbana por séculos no Brasil, ficando os assentamentos humanos mais restritos aos terrenos menos sujeitos ou a salvo de inundações periódicas, como os terraços fluviais ou os áreas ainda mais altas, como, no caso de São Paulo, as colinas desenvolvidas em rochas sedimentares (Ab'Saber, 2007; Seabra, 1987; Luz, 2014). O desenvolvimento industrial e urbano observado principalmente a partir do fim do século XIX em diversas regiões do globo promoveu uma crescente demanda por terra nas cidades, fazendo com que as planícies de inundação e os canais fluviais passassem a ser progressivamente urbanizados (Hockin; Whittle; Bailey, 1978; Douglas, 1983) (Figura 2). Esse processo resultou em modificações intencionais e diretas nos canais dos rios, bem como na urbanização das planícies de inundação (várzeas).

Figura 2 - Modelo de ocupação urbana da planície de inundação
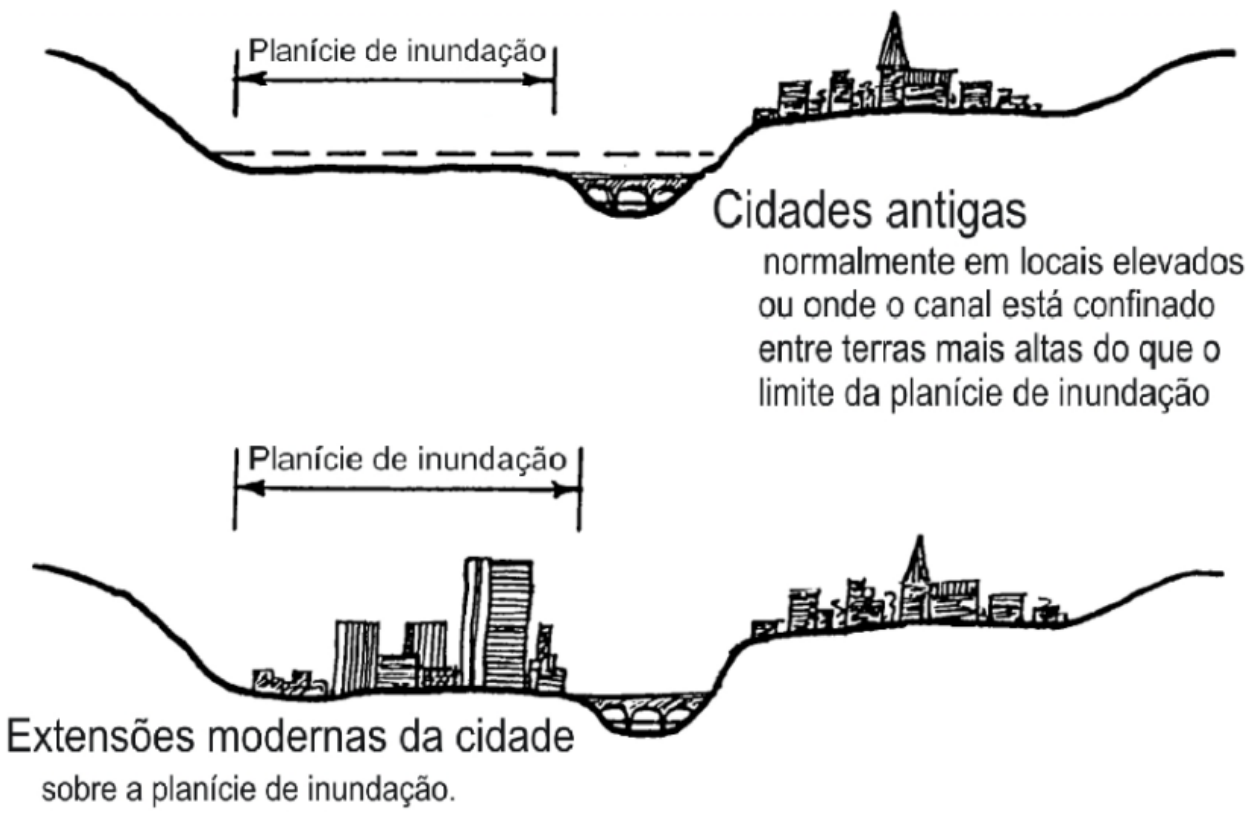

fonte: Adaptado de Hockin, Whittle e Bailey (1978). 
Assim, a expansão urbana tem resultado em intervenções diretas nessas formas fluviais, como, por exemplo, a construção de reservatórios e sistemas de drenagem, a retificação e ampliação da seção transversal de canais fluviais, a construção de margens e diques artificiais, a disposição de aterros sobre planícies de inundação e a ocupação generalizada de terrenos originalmente ocupados por inundações. Na maioria das vezes, esse conjunto de intervenções resulta na redução da capacidade original de atenuação das cheias, funcionalidade hidrológica própria de vastos setores dessas planícies (Douglas, 1983; Hockin, 1985; Gregory, 1987). Muitas vezes, a perda dessa funcionalidade é acompanhada de um correto dimensionamento para aumentar a área de seção transversal do sistema canal no sentido de compensá-la. Mesmo assim, o aumento da magnitude das vazões de pico gerados em bacias altamente urbanizadas e com altas taxas de condutos ultrapassa os valores adotados em projetos hidráulicos. Também concorre para esse quadro a dificuldade de fazer desassoreamentos na frequência adequada. Consequentemente, as enchentes tornaram-se constantes e estão entre os principais problemas das cidades.

As grandes cidades brasileiras não escaparam desse modelo de ocupação, e a urbanização de São Paulo ocorreu primordialmente nos últimos cem anos, como mostra o crescimento populacional a partir de 1871 (Figura 3). Nesse período, os sistemas fluviais dos rios paulistanos passaram a ser intensamente modificados para receber parte das estruturas urbanas da cidade.

\section{Figura 3 - Crescimento populacional no município de São Paulo e na Região Metropolitana de São Paulo (RMSP) entre 1871 e 2011}

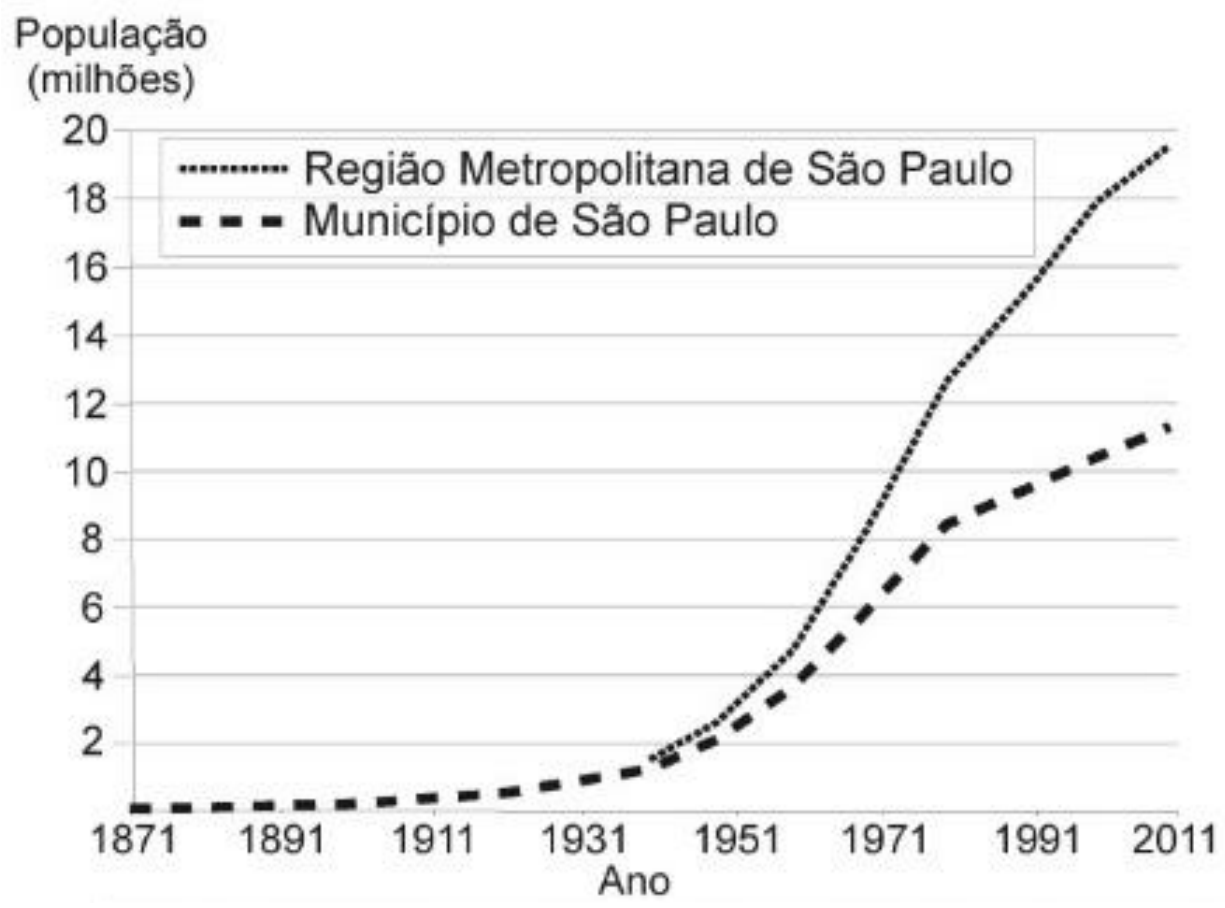

fonte: IBGE. Censos demográficos. 
Um dos mais importantes e emblemáticos rios da cidade era o Pinheiros, que, segundo Ab'Saber (1978), seria o rio de médio porte mais transformado na cidade de São Paulo e talvez de todo o mundo tropical.

Antes da urbanização, a planície fluvial do rio Pinheiros era um sistema meândrico típico das regiões de clima tropical úmido, apresentando um canal único com grande sinuosidade, ou seja um rio cheio de curvas, situado no centro de um vasto cinturão meândrico e de uma vasta planície de inundação, com a presença de lagos em ferradura e morfologia de terraços (Figura 4). Ab’Saber (2007) e Luz e Rodrigues $(2013,2015)$ identificaram ao menos dois níveis de terraços na planície fluvial do rio Pinheiros, além de dois níveis topográficos de fracos gradientes na própria planície de inundação.

\section{Figura 4 - Planície fluvial do rio Pinheiros em 1933, com destaque para algumas morfologias e portos de areia}

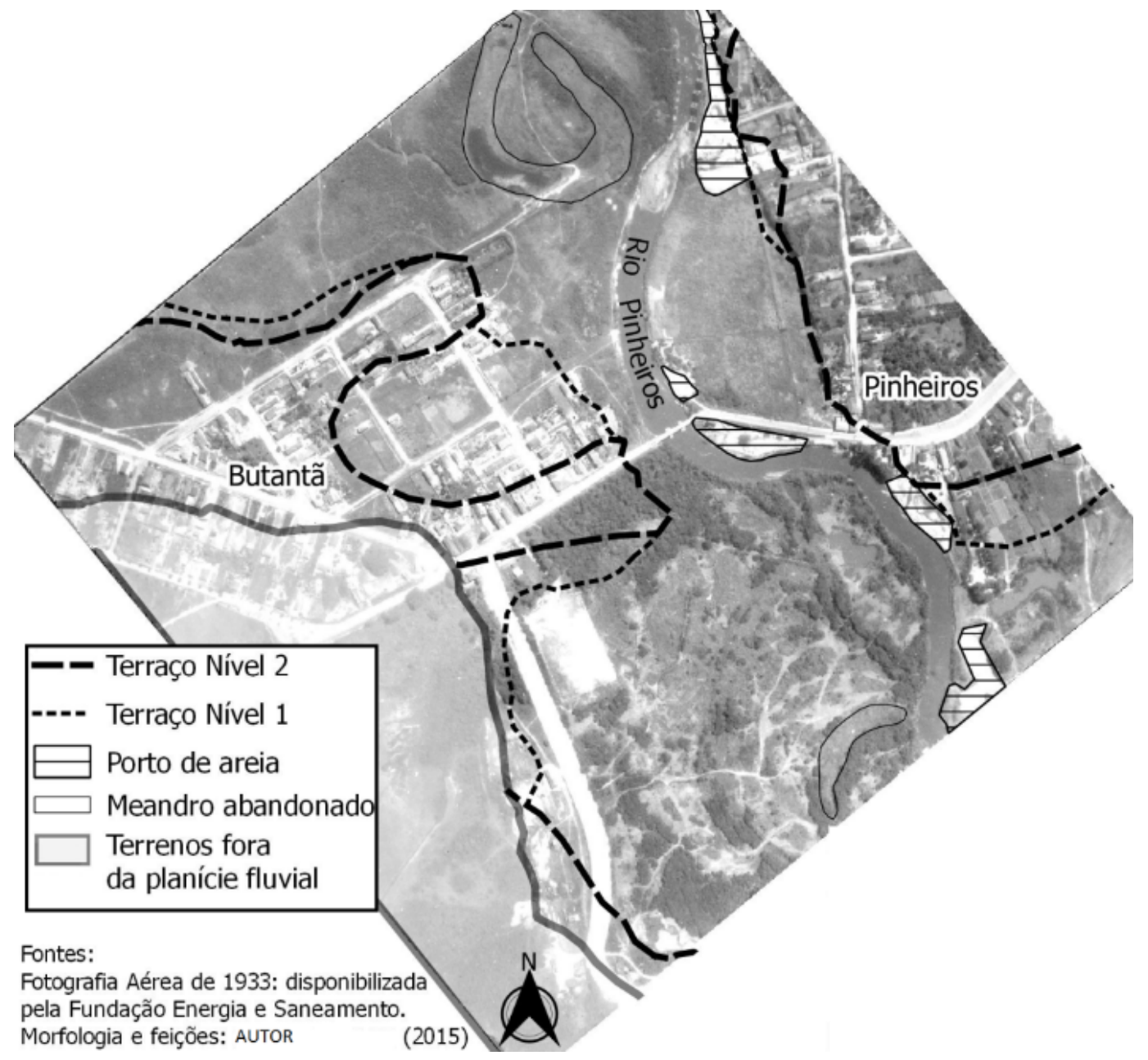

organização: Rodolfo A. da Luz.

O objetivo central do artigo é aprofundar a caracterização geomorfológica dessas transformações centenárias e, ao mesmo tempo, avaliar seu significado na mudança dos padrões de processos de inundação e enchentes. Para tanto, usaram-se as ferramentas da geomorfologia antropogênica, principalmente a cartografia geomorfológica retrospectiva, a abordagem histórica e os geoindicadores (Rodrigues, 2004). 
Os mapas ocupam um lugar central na metodologia adotada, uma vez que são utilizados como parâmetros evolutivos geomorfológicos da própria morfologia urbana, uma das modalidades mais relevante de morfologia antropogênica, aqui interpretada por meio dos mapas de uso e ocupação da planície.

Assim, elaborou-se o mapa da evolução da urbanização sobre a planície fluvial do rio Pinheiros. A ocupação até o ano de 2002 foi compilada do "Mapa da Área urbanizada, segundo períodos de expansão da Região Metropolitana de São Paulo", elaborado pela Secretaria Municipal de Planejamento de São Paulo. Para identificar áreas ocupadas depois disso, usaram-se imagens de satélite do aplicativo Google Earth Pro 7.3.2. O significado morfológico (morfologia antropogênica) desses mapas foi interpretado a partir de sua comparação com o mapa da morfologia original da planície, conforme apresentado por Luz (2014).

Esse procedimento permitiu a correlação espacial entre os dois planos de entendimento morfológico, o da morfologia original e antropogênica (da urbanização), revelando até mesmo parte das características, dos agentes sociais e dos motores do processo de urbanização em cada morfologia ou em cada subsistema fluvial da planície.

\section{Processo de ocupação urbana do sistema fluvial}

A expansão urbana sobre a planície fluvial é apresentada na Tabela 1 e na Figura 5. A urbanização na região pode ser sistematizada em três momentos: (1) até a década de 1930, (2) da década de 1930 à de 1990 e (3) da década de 1990 até os dias atuais.

\section{Tabela 1 - Porcentagem da área ocupada pela urbanização em cada} morfologia da planície fluvial do rio Pinheiros por período histórico

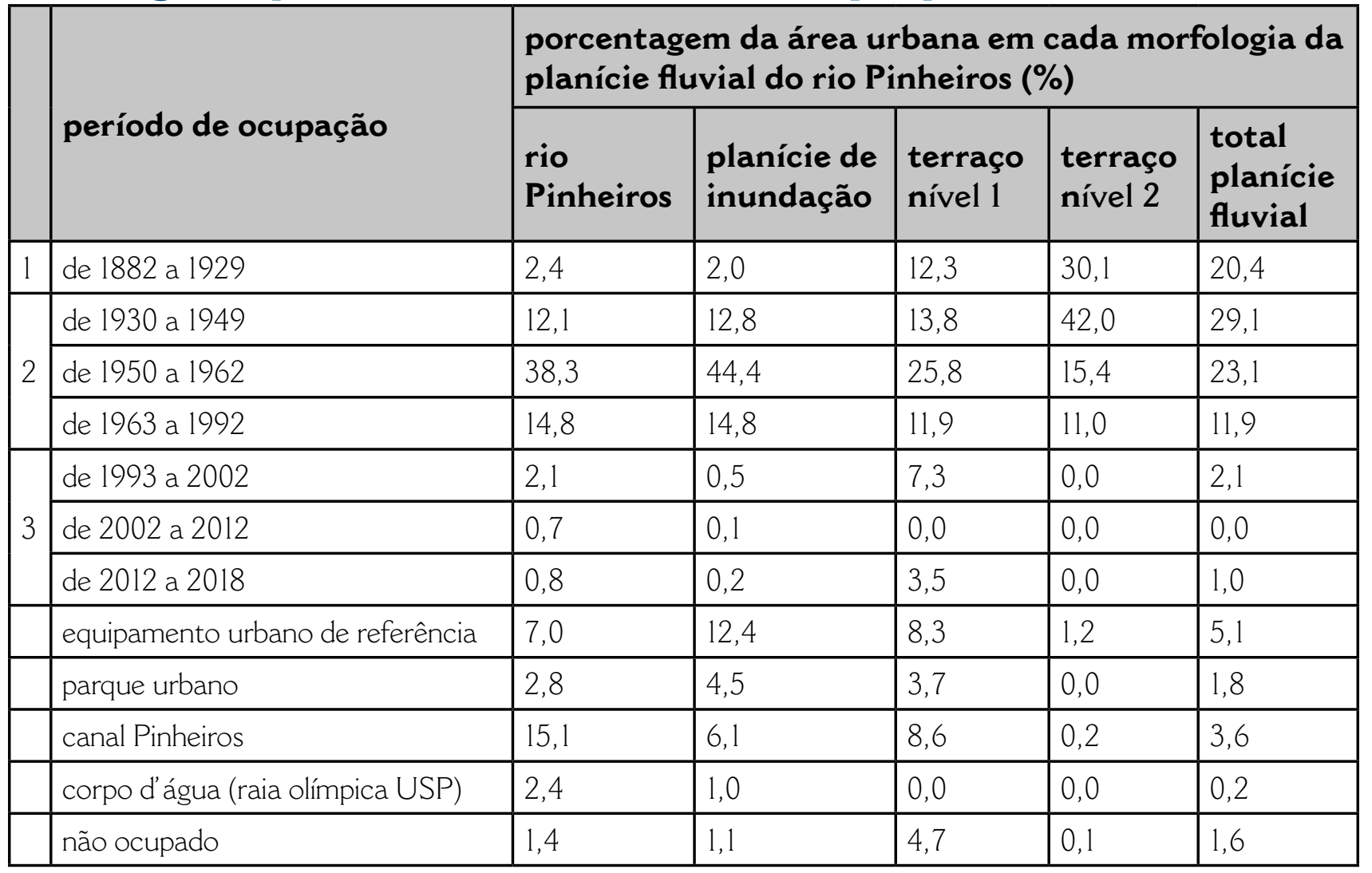


Figura 5 - Expansão urbana sobre a planície fluvial do rio Pinheiros

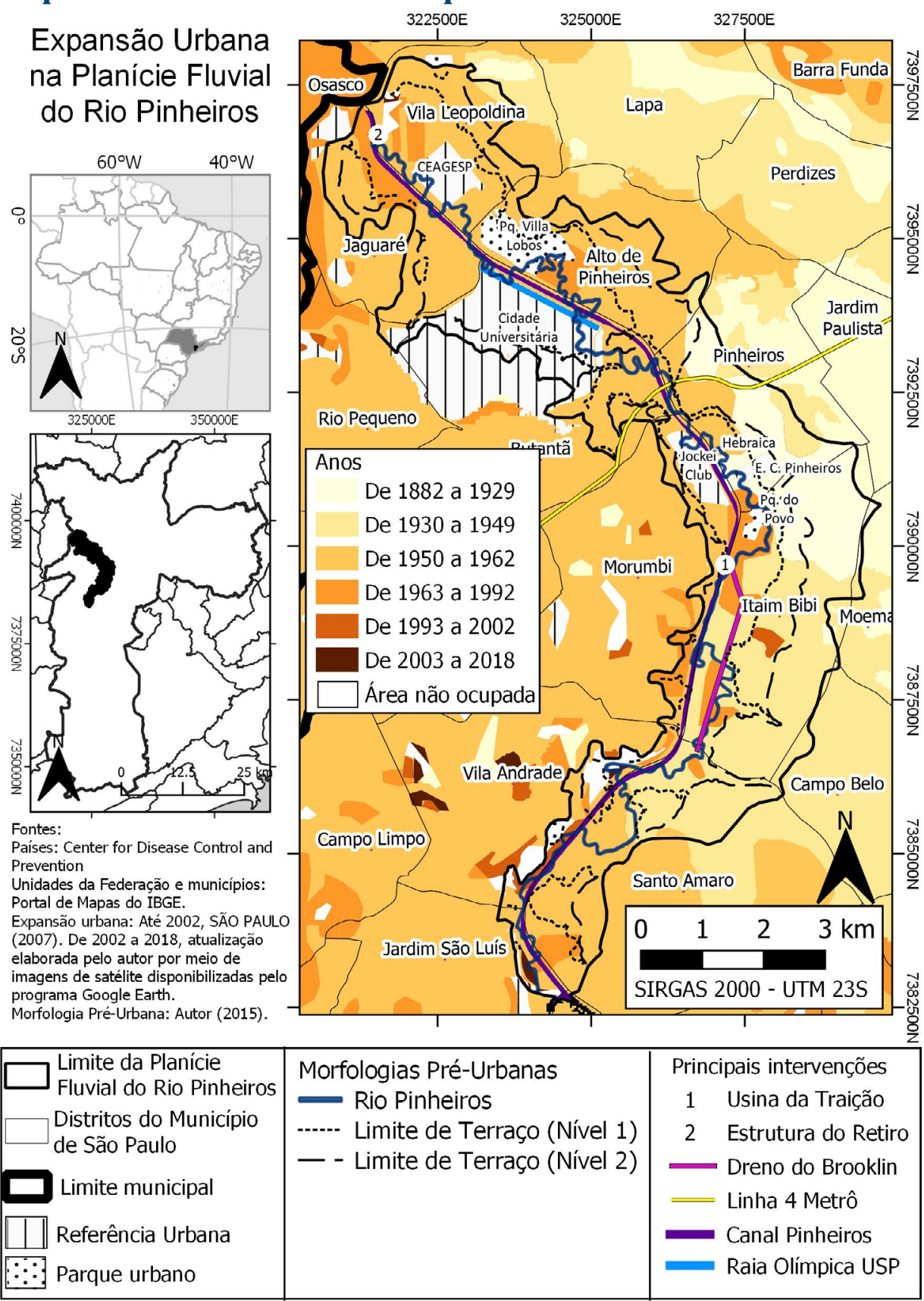

elaboração: Rodolfo A. da Luz.

\section{Até a década de 1930. A aurora da urbanização: múltiplos usos das águas e das várzeas}

A urbanização sobre a planície de inundação do rio Pinheiros tem início com intervenções setoriais no começo do século XX, concomitantes à expansão industrial da cidade, que passa a usar os recursos hídricos e minerais da planície para produzir energia elétrica e apoiar a construção civil. Até então, vilas desenvolvidas a partir de antigos aldeamentos indígenas estavam sobre alguns de seus terraços fluviais mais elevados, como é o caso dos bairros de Pinheiros e Santo Amaro. Antes disso, o canal meândrico foi utilizado para navegação. Primeiro pelos índios, depois pelos jesuítas e viajantes vindos da Baixada Santista, 
que, pelo Pinheiros, acessavam Tietê e Tamanduateí, chegando então ao centro da cidade (Pontes, 1995).

A primeira grande intervenção antrópica na planície fluvial foi de caráter hidráulico, em 1907, com a construção da represa de Guarapiranga integrando o rio Pinheiros ao sistema de aproveitamento hidroenergético que a Light ${ }^{1}$ começava a operar na Bacia Hidrográfica do Alto Tietê (Seabra, 1987; Pontes, 1995).

Segue-se a esse período a intensa retirada de areia e cascalho da planície de inundação e parte dos baixos terraços fluviais, que forneceu matéria-prima para a construção civil responsável pela edificação de uma cidade que crescia em ritmo alucinante. Os "portos de areia" foram elementos marcantes na paisagem da planície no início do século XX, mobilizando uma grande quantidade de material sedimentar e modificando a morfologia e os processos do sistema fluvial do Pinheiros por causa das escavações e da disposição de rejeitos. Segundo Seabra (1987), a mineração nos rios Tietê e Pinheiros registrou 515.200 $\mathrm{m}^{3}$ de areia e cascalho retirados em 1925, número que mais que dobrou em 1937, quando se registrou a retirada de $1.091 .820 \mathrm{~m}^{3}$.

Mesmo com a construção da represa de Guarapiranga e a mineração, a maior parte da morfologia original e dos processos hidromorfodinâmicos do sistema fluvial do Pinheiros ainda estava preservada nesse período e no trecho estudado, em particular. A ocupação urbana se restringia a apenas $2,4 \%$ do rio, $2 \%$ da planície de inundação e 12,3\% dos baixos terraços, concentrados nas proximidades do atual Jockey Club. Segundo Ab'Saber (2007), a larga planície do rio Pinheiros, com sua dinâmica de inundações, bem como a própria dinâmica de saturação de grande parte de seus solos, constituíam elementos impeditivos à expansão urbana da cidade nessa região.

No entanto, isso não impedia que o rio ou sua várzea se integrassem à cidade como fontes de recursos naturais e áreas de recreação, sendo parte da paisagem e cotidiano paulistano (Seabra, 1987). Esses terrenos eram utilizados para pastos de animais, por corporações militares que realizavam exercícios bélicos, por muitos campos de futebol (campos de várzea), pelos primeiros clubes de regatas e de desportos da cidade (como o Sport Club Germânia) e chácaras nos terrenos mais enxutos (Ab'Saber, 2007).

$\bigcirc$ fim desse período marca o início da preocupação com as inundações e seus impactos, ou seja, as enchentes. Em 1924, o engenheiro sanitarista Francisco Saturnino Rodrigues de Brito dirigiu um estudo para estabelecer um plano para o controle sanitário e das enchentes no trecho urbano do rio Tietê. No plano, sugere-se que partes das planícies de inundação fossem preservadas e transformadas em parques ou bosques que pudessem ser eventualmente inundados sem inconvenientes para a população. Uma das áreas destinadas a esse uso seria a região da confluência entre os rios Pinheiros e Tietê (Figura 6) (Brito, 1926).

1 São Paulo Tramway, Light \& Power Company Limited, ou simplesmente Light, empresa de capital canadense que foi responsável pela execução das obras de retificação e alargamento do canal do Pinheiros, bem como da operação dos reservatórios e estruturas hidráulicas do sistema até meados do século XX. 
Figura 6 - Excerto do Plano de Melhoramentos do rio Tietê dirigido por Saturnino de Brito. Detalhe da área destinada a um parque na confluência do Tietê e do Pinheiros, onde hoje é o Cebolão

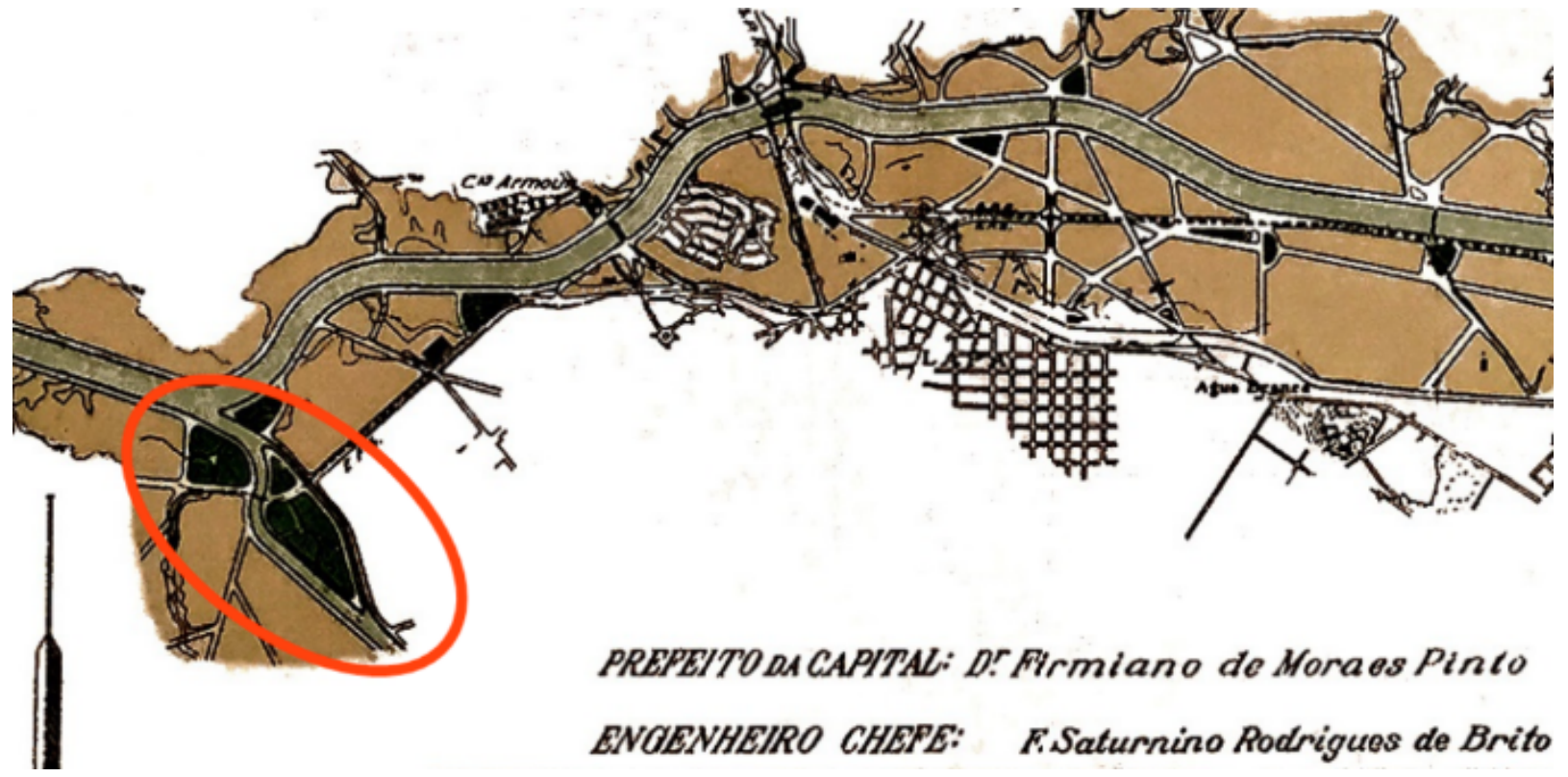

fonte: Brito (1926).

No entanto, em 1928, esse plano passou a ser dirigido pelo engenheiro João Florence de Ulhôa Cintra, que alterou substancialmente a proposta de Saturnino Brito, eliminando do projeto a preservação de setores da planície de inundação. Em seu lugar, se projetaram as atuais avenidas marginais, alinhando o uso das margens dos rios paulistanos às diretrizes do Plano de Avenidas de Prestes Maia, já voltado para a expansão rodoviária (Santos, 2014).

\section{Da década de 1930 à de 1990. O boom da urbanização: geração de energia e tráfego de automóveis}

A década de 1920 culminou com o Plano de Avenidas de Prestes Maia, porém também foi marcada pela escassez de energia elétrica na cidade (Pontes, 1995), que consistiu no argumento central para a implantação de projetos de engenharia que transformaram completamente o sistema fluvial do Pinheiros. Em 1925, começou a se tornar realidade o Projeto Serra, idealizado por engenheiros da Light e que buscava aproveitar o desnível altimétrico da Serra do Mar, revertendo águas do planalto para a geração de energia hidroelétrica na Baixada Santista. Para tanto, foi preciso represar as águas do Rio Grande (um dos formadores do Pinheiros) e inverter seu fluxo para o leito do Rio das Pedras (que flui em direção à Baixada Santista, já na Bacia Hidrográfica do Rio Cubatão) (Figura 7).

Em 1927, os idealizadores do projeto alegaram a necessidade de inverter as águas do Pinheiros e substituir seu leito meândrico por um canal artificial, para que parte das águas do Tietê fosse encaminhada para reservatórios construídos nos formadores do Pinheiros. 


\section{Figura 7 - Sistema hidráulico artificial no canal do Pinheiros}

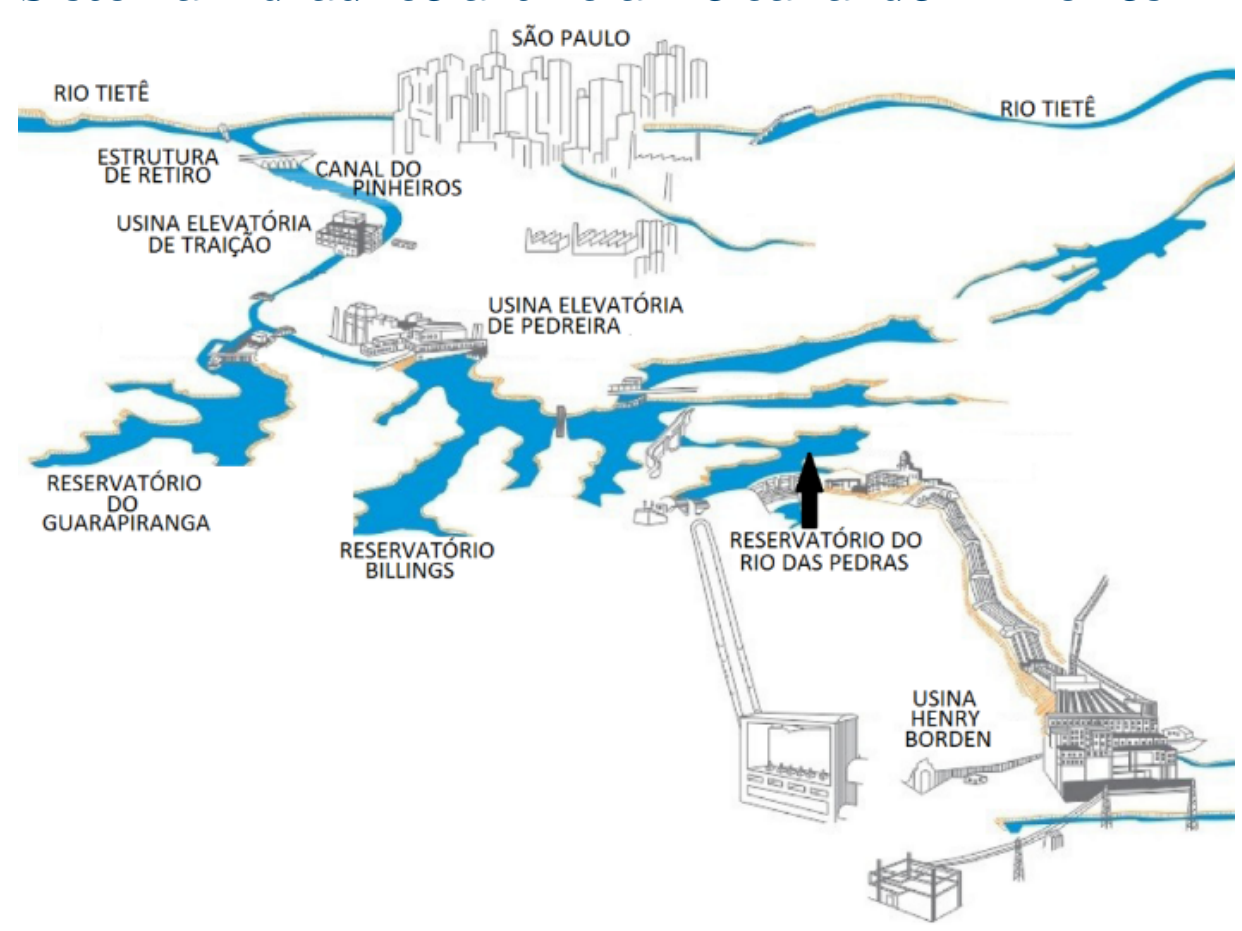

fonte: Modificado de Emae ([s.d.]).

Além do canal artificial, foram construídas a represa do Rio Grande em 1927 (atual represa Billings), as usinas elevatórias de Pedreira em 1939 e da Traição em 1940 e a Estrutura do Retiro em 1942, com a finalidade de controlar o fluxo de água entre os dois rios em casos de cheia (Diniz; Ferrari, 1995) (Figura 7).

Como resultado, o rio Pinheiros, que tinha 33,7 km de extensão e 29,8 m de largura média, foi substituído por um canal artificial retificado dividido em duas partes pela Usina da Traição, com 25,8 km de extensão (da foz até a represa Billings) e média de 85 m de largura (Luz; Rodrigues, 2015). A declividade praticamente nula e a baixíssima vazão, em torno de 10 $\mathrm{m}^{3} / \mathrm{s}$ (Pena, 2008), fazem com que o canal se comporte como uma sequência de lagos, e não mais como um canal propriamente fluvial (Emae, 2009; Luz; Rodrigues, 2015).

Assim, a construção do canal artificial extinguiu o rio Pinheiros. Além disso, essas obras tornaram possível a reversão do curso do agora Canal do Pinheiros de jusante para montante, em direção as represas Guarapiranga e Billings, implicando grandes mudanças no sistema geomorfológico, comparáveis a eventos naturais extremos e instantâneos ou a eventos milenares (curto-prazo, de $10^{3}$ a $10^{4}$ anos) (Luz, 2014).

Como resultado das intervenções, a planície de inundação e os baixos terraços deixaram de ser habitualmente inundados por extravasamento do canal, e seu solo, que antes era úmido, foi drenado. Um conturbado processo de especulação imobiliária marcou a urbanização desses terrenos. No contrato de concessão das obras, foi conferida à Light a faculdade de desapropriar as "áreas alagadiças ou sujeitas a inundações”, tornando a empresa dona de grande parte das terras da planície de inundação e dos baixos terraços fluviais drenados pelas intervenções de engenharia (Seabra, 1987, 1995).

As obras foram entregues para a administração pública em 1957 (Pontes, 1995). O processo de apropriação dos novos terrenos pela Light resultou em $20.779 .443 \mathrm{~m}^{2}$ de terra para a 
empresa, dos quais apenas 4.015.360 $\mathrm{m}^{2}$ foram destinados a estruturas de engenharia (Canal do Pinheiros, linha de transmissão de energia elétrica, ferrovia e avenidas marginais), restando 16.764.083 $\mathrm{m}^{2}$ de terras que foram dirigidas à especulação imobiliária encabeçada pela Light (Seabra, 1987; Pontes, 1995).

Assim, a morfologia original da planície meândrica foi completamente transformada e, com ela, seus processos característicos. Além da extinção do rio Pinheiros, a antiga planície de inundação (várzea) foi transformada num novo nível terraceado devido aos aterros antrópicos e à nova dinâmica de cheias que se instalou no sistema fluvial após as obras da Light (Luz, 2014). Esses aterros são compostos principalmente por lixo (Seabra, 1987), mas outros materiais antropogênicos também foram despejados na área ao longo da história, como rejeitos de escavações de obras diversas (bota-fora) como as do Metrô de São Paulo, rejeitos do desassoreamento do canal, entulho etc. (Rodrigues, 2006).

Como visto, a urbanização da cidade de São Paulo no período era orientada pelo Plano de Avenidas de Prestes Maia, resultando na construção de vias expressas marginais ao canal artificial, sobre as planícies de inundação da cidade (Custódio, 2002). Essa lógica urbanística, aliada às intervenções da Light e à drenagem dos antigos terrenos úmidos que eram constantemente atingidos por inundações, permitiu que construções e vias ocupassem os novos níveis terraceados formados sobre a antiga planície de inundação.

Assim, catalisada pelos projetos de engenharia hidráulica e pelo Plano de Avenidas, a urbanização se apropriou da planície de inundação e baixos terraços (80,3\% do rio Pinheiros, $78,2 \%$ da planície de inundação e 60,2\% dos baixos terraços). Primeiramente, antigos bairros da cidade, que têm seu núcleo em altos terraços fluviais, como Pinheiros, Butantã, Santo Amaro e Itaim Bibi, se estenderam em direção ao canal retificado (Seabra, 1987), fosse por zonas residenciais como o Alto de Pinheiros e na City Butantã, fosse por grandes zonas industriais como o Jaguaré, a Vila Leopoldina e Santo Amaro. Outras partes foram destinadas a equipamentos urbanos, clubes e usos diversos, como a Cidade Universitária, o Jockey Club, a Ceagesp (Companhia de Entrepostos e Armazéns Gerais de São Paulo), o Esporte Clube Pinheiros (antigo Sport Club Germânia) e o clube da Hebraica (Figura 5).

As áreas atingidas pelas inundações por extravasamento do Canal Pinheiros foram reduzidas por essas intervenções de engenharia de alta magnitude, que incluíram o aumento da seção transversal (calha), a implantação de barragens que impedem o refluxo das águas do rio Tietê e a implantação de reservatórios a montante e de bombas para reversão do fluxo d'água. No entanto, há tipos de enchente que foram criadas ou potencializadas pela nova morfologia antrópica e persistem na planície, com demonstra Luz (2014). Essas enchentes decorrem de aterros, de obras hidráulicas e de drenagem urbana, impermeabilizações, falta de desassoreamento ou do próprio sistema viário, que atua de forma combinada com a morfologia original (Figura 8 e Quadro 1).

Nota-se que cerca de 81\% das enchentes mapeadas por Luz (2014) dentro da planície fluvial têm seus pontos situados no antigo rio Pinheiros, planície de inundação ou baixos terraços. Outros estudos chegam a conclusões similares. Berges (2013), por exemplo, verificou que $99 \%$ das enchentes estudadas num período de 40 anos ocorreram no interior do compartimento original da planície de inundação do Córrego da Mooca. 


Quadro 1 - Tipos de enchentes na planície urbanizada do Pinheiros
\begin{tabular}{|l|l|}
\hline tipo de enchente & descrição \\
\hline por refluxo & $\begin{array}{l}\text { Ocorre quando o canal Pinheiros impede o fluxo das águas dos tributários e das } \\
\text { galerias pluviais. O lugar mais crítico desse tipo de inundação é a Ceagesp. }\end{array}$ \\
\hline $\begin{array}{l}\text { em avenidas de fundo } \\
\text { de vale }\end{array}$ & $\begin{array}{l}\text { Ocorre nas antigas planícies dos rios e córregos tributários do canal Pinheiros, onde } \\
\text { foram construídas avenidas como a Roque Petroni Júnior, a Cidade Jardim/Nove de } \\
\text { Julho e a Jornalista Roberto Marinho. }\end{array}$ \\
\hline $\begin{array}{l}\text { potencializadas por } \\
\text { aterros }\end{array}$ & $\begin{array}{l}\text { Ocorre nos terrenos mais baixos da antiga planície de inundação, que estão } \\
\text { separados do canal Pinheiros por aterramentos. Esses aterros barram o fluxo das } \\
\text { águas em direção ao canal. }\end{array}$ \\
\hline $\begin{array}{l}\text { causadas por } \\
\text { estrutura de drenagem } \\
\text { deficiente }\end{array}$ & $\begin{array}{l}\text { Rede de bueiros e galerias de águas pluviais que não dão conta da descarga pelo } \\
\text { aumento do escoamento superficial na bacia de contribuição, por subestimação da } \\
\text { capacidade ou por falta de manutenção. }\end{array}$ \\
\hline $\begin{array}{l}\text { por extravasamento de } \\
\text { canal }\end{array}$ & $\begin{array}{l}\text { Menos recorrentes do que no passado, limitadas principalmente a pontos específicos } \\
\text { das vias marginais, onde a pista de rolamento é rebaixada para permitir a passagem } \\
\text { de caminhões altos por sob a pontes. }\end{array}$ \\
\hline
\end{tabular}

fonte: Luz (2014).

\section{Figura 8 - Pontos e tipo de enchente na planície fluvial do rio Pinheiros}

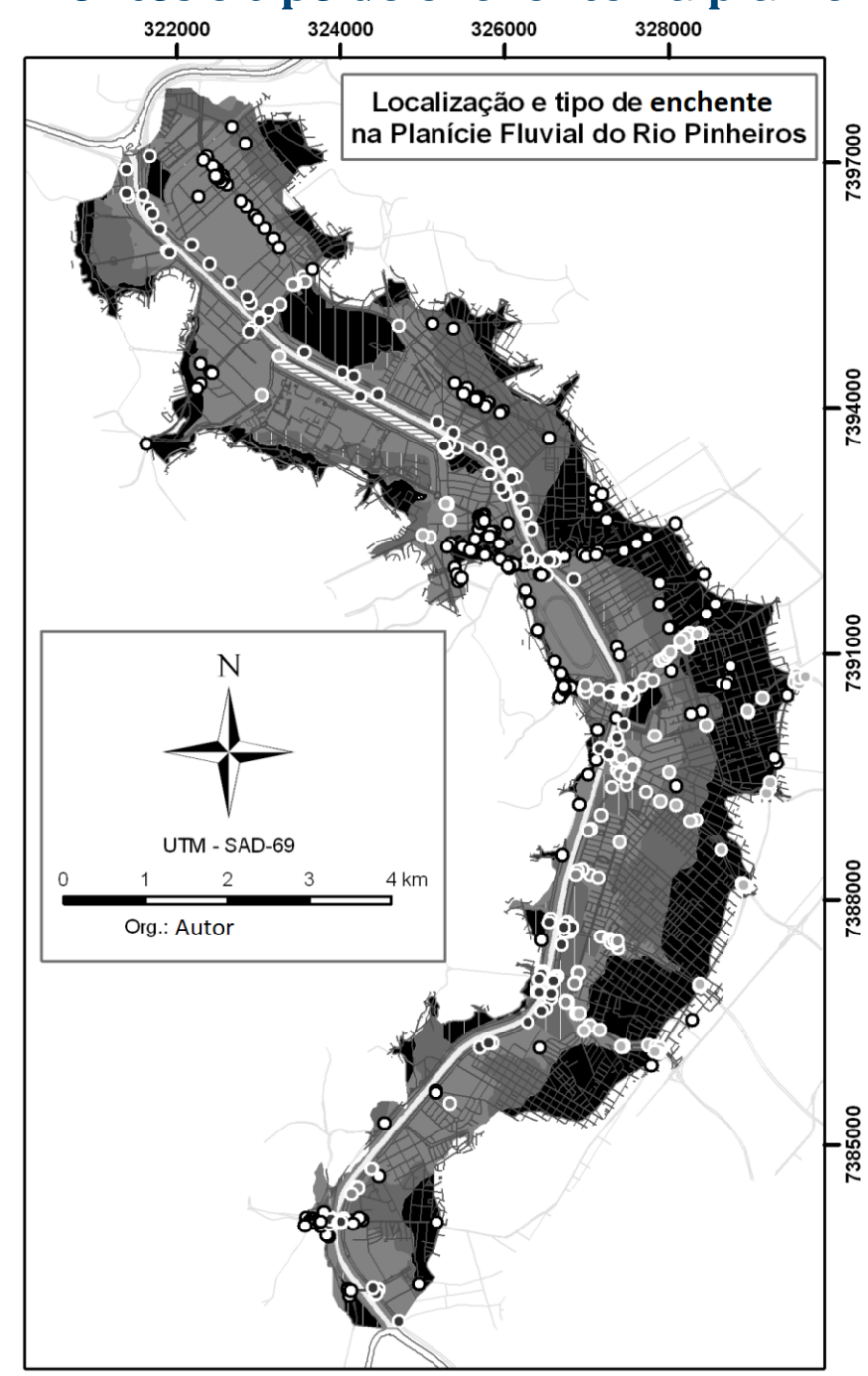

Base Cartográfica

ㄴ Sistema viário

J Joquei Clube

Unidades Geomorfológicas

$\square$ Canal Pinheiros

$\Longleftrightarrow$ Raia olímpica USP

¿े Terraço Nível 1

Urbanização sobre a antiga

planície de inundação

Terraço Nível 2

Nivel original urbanizado

Aterros

은 Terraço Nível 3

Nível original urbanizado

II Aterros

Pontos de inundação e causas predominantes

- Avenidas de fundo de vale

- Potencializada por aterros

- Extravasamento do canal

Sem causa predominante definida

遖

fonte: Fusp (2009) e dados fornecidos pelo Centro de Gerenciamento de Emergências da Prefeitura de São Paulo (CGE) compilados em Luz (2014). 


\section{Da década de 1990 até os dias atuais. Das residências e indústrias aos arranha-céus}

Nos anos 1990, 95,2\% da planície fluvial já estava tomada pela urbanização (incluindo parques e equipamentos urbanos), restando apenas pequenas manchas desocupadas, predominantemente sobre baixos terraços. Tem início uma nova etapa de intervenção, caracterizada pela substituição de antigas residências e indústrias por arranha-céus, shopping centers, hotéis, casas de espetáculo, empreendimentos multiuso e condomínios verticais de altíssimo padrão. Tudo isso acompanhado de grandes investimentos públicos na construção de pontes, túneis, ampliação de avenidas, modernização do sistema de trens metropolitanos que atravessa a planície de norte a sul e a construção de um túnel de metrô por baixo do Canal do Pinheiros (Linha 4 - Amarela) (Fix, 2007, 2009).

Nos distritos de Pinheiros e Itaim Bibi (incluindo os bairros Vila Olímpia, Cidade Jardim e Brooklin), principalmente ao longo das avenidas Brig. Faria Lima e Luís Carlos Berrini e da Marginal Pinheiros, as antigas planícies de inundação foram transformadas em uma das regiões mais valorizadas da cidade de São Paulo (Hepner, 2010). É uma parte da cidade que concentra investimentos privados voltados a negócios imobiliários controlados pelo capital local e investimentos públicos voltados à modernização da infraestrutura, muitas vezes combinados na forma de parcerias público-privadas, marcadas pelo direcionamento de recursos públicos para alavancar negócios privados e pela expulsão dos moradores de baixa renda da região (Fix, 2004).

Essas grandes edificações têm gerado grandes intervenções no subsolo. Alguns empreendimentos chegam a usar de três a sete níveis subterrâneos, principalmente para acomodar vagas de estacionamento, tornando constante o bombeamento do lençol freático para evitar o alagamento das garagens, como mostra a presença de água nas guias e sarjetas (Kayo, 2013) (Figura 9).

Esse tipo de urbanização mais recente, que amplia a intervenção no subsolo (túneis, dutos e fundações profundas) de terrenos com alta fragilidade como os da planície fluvial, pode implicar instabilidades geotécnicas que vão desde a simples formação de buracos nas vias até a ocorrência de acidentes graves como o da escavação do poço da estação Pinheiros e do túnel do metrô em 12 de janeiro de 2007, que resultou na morte de sete pessoas. Luz (2014) e Luz e Rodrigues (2015) destacam que, além dos altos níveis do lençol freático típico das planícies de inundação e baixos terraços, há na planície do Pinheiros uma complexa variabilidade estratigráfica vertical e lateral que potencializa suas fragilidades geotécnicas. Kayo (2013) destaca os constantes bombeamentos do lençol freático realizados no subsolo da planície, que também podem resultar em instabilidades geotécnicas.

Em antigas zonas fabris, como Vila Leopoldina, Jaguaré e partes de Santo Amaro, os galpões industriais estão sendo substituídos por imensas torres residenciais, também com fundações profundas e necessidade de bombeamentos do lençol freático, potencializando problemas de mobilidade urbana devido à falta de um sistema viário adequado ao crescente número de habitantes, assim como a consequente pressão sobre a administração pública para intervenções de infraestrutura viária nesses bairros (Angeli, 2011). 


\section{Figura 9 - Esquema de bombeamento do lençol freático por grandes edificações}

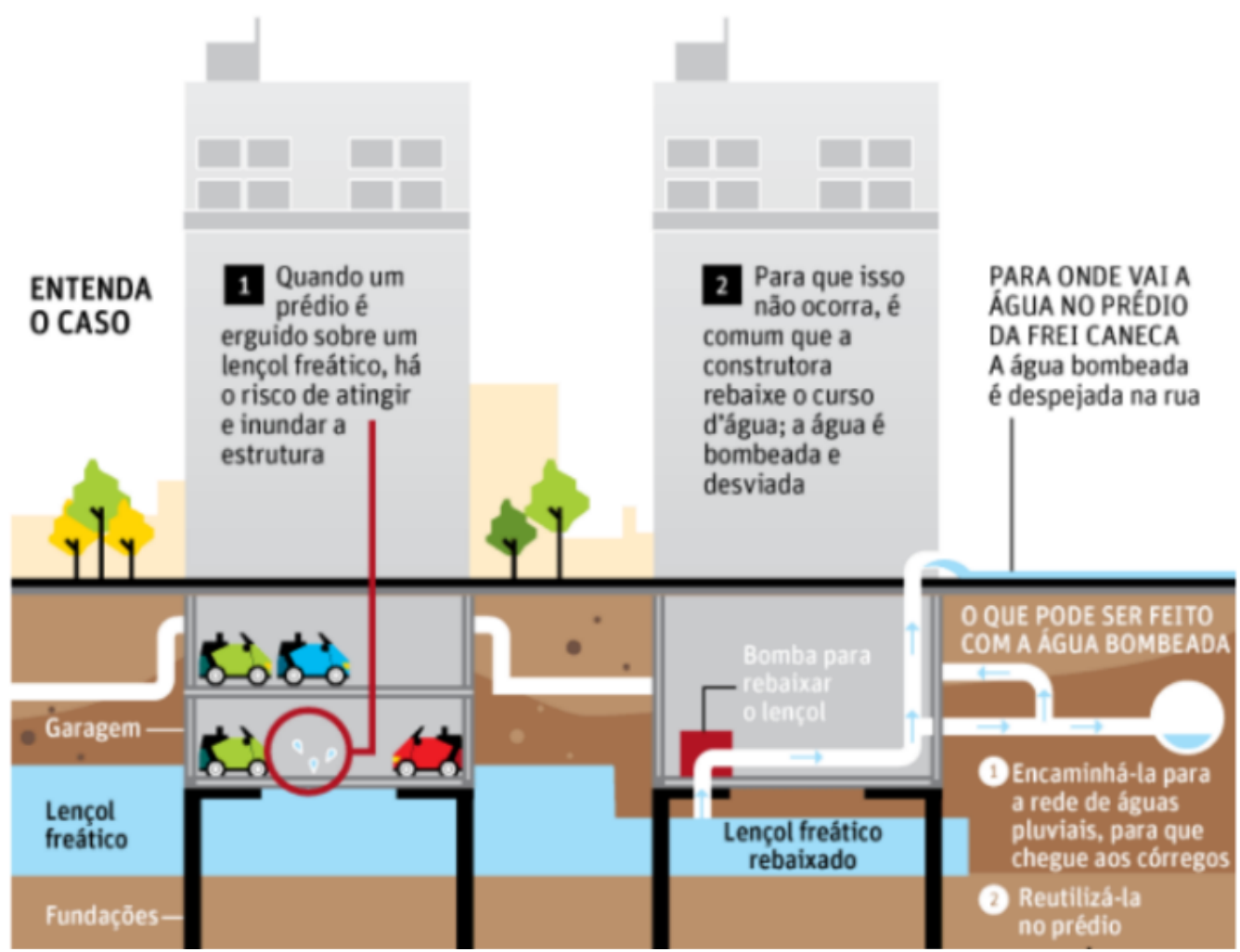

fonte: Gallo e Gerarque (2012).

Além de comportar um dos principais centros financeiros da cidade, Oseki (2000) destaca que a planície do Pinheiros configura hoje um espaço de redes, suportando um dos mais importantes eixos de circulação de mercadorias da cidade, fazendo com que o canal e sua várzea não sejam mais um lugar de vivência ou moradia para a maioria da população que mora ou trabalha nas proximidades.

Essa vivência só pode ser experimentada em parques, e foram instalados na área dois: um deles é Parque Villa Lobos, implantado durante a década de 1990 na região do Alto de Pinheiros e Vila Leopoldina, sobre um aterro de 3 a 4 metros de altura composto por resíduos sólidos, entulho e material oriundo de obras como as do metrô (Figura 10) (Luz, 2014).

Figura 10 - Parques urbanos e aterros: (a) depósitos antropogênicos que compõem o aterro do Parque Villa Lobos; (b) talude de 3 a 4 metros do Parque Villa Lobos; (c) Aterro do Parque do Povo

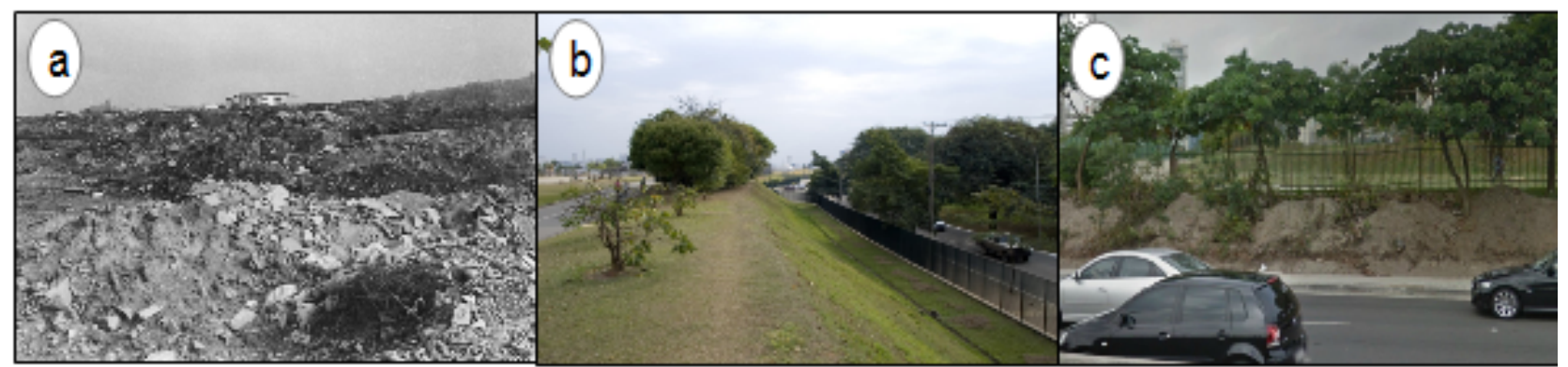

fontes: (a) Acervo do Parque Villa Lobos (Rodrigues, 2006); (b) foto: Eduardo Justiniano (Rodrigues, 2006); (c) GoogleStreetView (2014, imagem de nov. 2013). 
O outro é o Parque do Povo, implantado em 2006 na região do Itaim Bibi, num terreno antes ocupado por agremiações esportivas, sobretudo de futebol, últimos remanescentes dos "campos de várzea" na planície do Pinheiros que, segundo Scifoni (2013), foram expulsos da área para a implantação desse parque.

Mas esses parques funcionam apenas como áreas de lazer, longe da função hidrológica proposta por Saturnino Brito na década de 1920 para os parques varzeanos, que era a de armazenar temporariamente as águas das enchentes durante os picos de cheias. Mesmo que se a retomasse, tal ideia encontraria dois grandes impeditivos: (1) os espessos aterros que compõem esses parques, deixando-os em posição topográfica elevada, e (2) a separação física entre os parques e o canal do Pinheiros pelas vias expressas e a ferrovia, impedindo que as águas do canal sejam direcionadas aos parques sem grandes intervenções de engenharia. ${ }^{2}$

\section{Enchentes, o permanente problema urbano}

A urbanização da planície fluvial do Pinheiros variou no tempo e no espaço. De acordo com Fix (2004), desde as intervenções e apropriações da Light até os dias atuais, essa urbanização foi possibilitada por uma articulação entre capital financeiro internacional, mercado de terras, legislação urbanística e redes de infraestrutura. Cada nova fase de intervenção antrópica na planície representa novos momentos de perturbação do sistema fluvial por atividades humanas, mas podemos afirmar que as obras da Light definem o momento de maior intervenção, responsável pela artificialização quase completa do sistema hidrológico da planície fluvial do rio Pinheiros.

Como o próprio nome diz, as planícies de inundação recebem periodicamente as águas dos transbordamentos dos canais, funcionando como uma espécie de reservatório natural e temporário das águas das chuvas, que retornam para os rios após a passagem da chamada onda de cheia. Portanto, elas atenuam o impacto das inundações armazenando temporariamente parte da água das cheias.

A urbanização sobre as antigas áreas atingidas pelas inundações, notadamente a partir da década de 1930, fez com que a população que veio ocupar estas áreas passasse a ter que enfrentar as enchentes, que se torna assim um problema urbano. A falta de terrenos aptos a receber as águas das inundações durante os períodos chuvosos, tão comuns dos verões paulistanos, resultou num grande impacto social e econômico das enchentes em São Paulo.

Seabra (1987) afirma que as pioneiras intervenções de engenharia na planície fluvial do Pinheiros tinham já objetivos contraditórios: se, por um lado, as represas da Light deviam estar sempre cheias para possibilitar a produção de energia elétrica, por outro lado, deviam estar sempre vazias para um efetivo controle das enchentes.

Historicamente, a solução para a região sempre foi a construção de estruturas de engenharia para tentar controlar as águas e minimizar os efeitos das enchentes no sistema fluvial. A construção do canal mais largo e profundo que o antigo rio Pinheiros e o sistema de reversão

2 Para mais informações sobre parques urbanos em planícies de inundação que, além de ser áreas de lazer, cumprem funções de controle de enchentes, consultar Environment Agency (2008) e Luz (2014). 
de águas para montante por meio de usinas elevatórias são exemplos de grandes estruturas de engenharia destinadas a controlar as cheias da planície (Emae, 2009).

Outro exemplo é a construção, em 1970, do Dreno do Brooklin (Blanes, 2006), um canal paralelo ao Canal do Pinheiros concebido para minimizar o problema das enchentes na região das desembocaduras dos córregos Traição, Águas Espraiadas e Cordeiro. Posteriormente, o dreno foi recoberto pela avenida Luís Carlos Berrini e a impermeabilização da bacia hidrográfica dos referidos córregos e o assoreamento do próprio dreno fez com que as enchentes persistissem no local (Custódio, 2002).

Os anos 1990 apresentam outra tentativa de solução: os piscinões. Piscinão é o termo popular dos reservatórios de detenção, que buscam reter as águas em diferentes pontos da bacia hidrográfica para atenuar os efeitos das enchentes a jusante. Sua lógica reflete uma mudança na forma de combater enchentes, pois seu princípio é o inverso do predominante até então, que era a expulsão das águas da bacia pelo aumento da capacidade dos canais por canalização, alargamento e retificação. ${ }^{3}$ Pode-se dizer que os piscinões visam justamente recuperar o papel hidrológico de planícies de inundação e baixos terraços perdidos durante a urbanização, que foram estimados em 90,03 x 106 $\mathrm{m}^{3}$ (Luz, 2014; Rodrigues et al., 2019).

Provavelmente o impacto das enchentes fosse menor se, em 1926, a proposta de Saturnino Brito tivesse sido levada adiante, uma vez que sua preocupação central era manter terrenos da planície livre de ocupação para receber as águas das cheias.

A luta para recuperar parte desses terrenos das antigas planícies só foi retomada nos anos 1980. Apesar de não considerarem especificamente a planície do Pinheiros, foram elaborados projetos que destacavam a importância da existência de áreas livres nas planícies para armazenamento das águas das cheias e consequente atenuação dos efeitos das enchentes.

O Projeto do Parque Tietê de 1986, por exemplo, do arquiteto Oscar Niemeyer, previa a remoção das vias marginais expressas e a desapropriação de 10 milhões de metros quadrados ao longo da margem esquerda do Tietê para a criação de um grande parque com habitações, escritórios, núcleos de lazer e esportes, áreas verdes, um centro cívico e um centro cultural.

No final do século XX, a prefeitura de São Paulo promoveu um concurso público de planos urbanísticos e ambientais para as margens dos rios paulistanos, e o projeto vencedor, proposto pela equipe do arquiteto Bruno Padovano (Figura 11), salientou novamente a necessidade de recuperar parte das funções hidrológicas do sistema (Monteiro, 2010). No entanto, como destaca Custódio (2002), interesses setoriais como os do mercado imobiliário impediram a implantação desses projetos.

3 Isso não significa que a lógica anterior tenha sido abandonada, como se verifica, por exemplo, no recente projeto de ampliação da calha do Tietê, executado entre 1998 e 2005 (Daee, [s.d.]). 


\section{Figura 11 - Concurso das marginais - projeto da equipe do arquiteto Bruno Padovano}

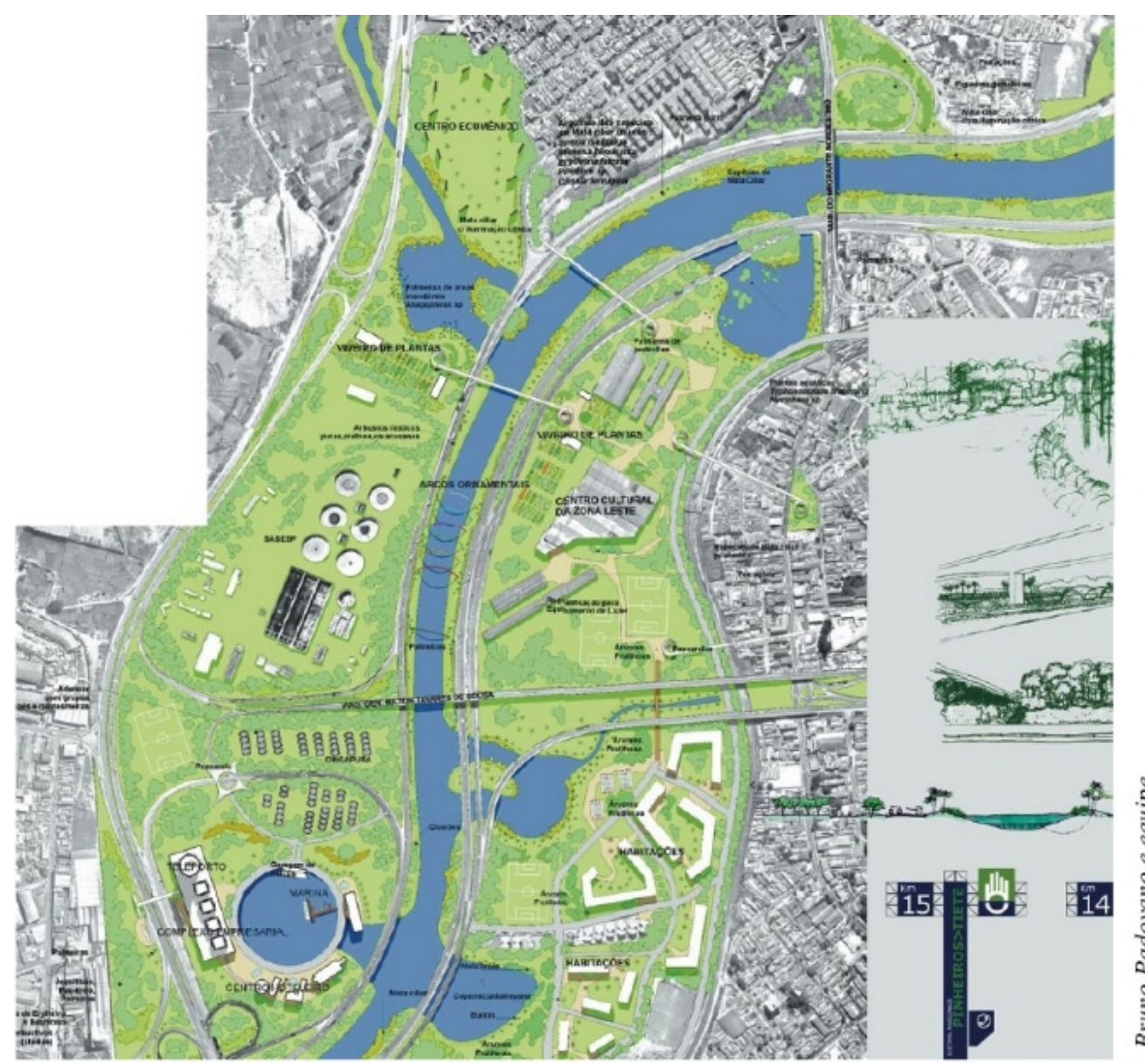

fonte: Monteiro (2010).

Considerando os estágios de urbanização delineados por Douglas (1983), podemos afirmar que só haverá um controle de enchentes mais efetivo quando a cidade de São Paulo romper o atual estágio de urbanização avançada, caracterizado por extensos terrenos impermeáveis e alta densidade de edificações, em direção ao estágio de requalificação urbana, quando se removem edificações, recuperam áreas degradadas e ampliam áreas verdes (conforme planos urbanísticos projetados mas nunca implantados).

Já em 1987, Seabra denunciava que a população não se dava conta da existência do rio Pinheiros ou de sua várzea, a não ser quando ocorriam enchentes e, acrescentamos, pelo odor fétido de suas águas poluídas. São justamente as enchentes que trazem à tona o antigo sistema fluvial encoberto e escondido pela cidade, e demonstram, a cada período chuvoso, a falta que fazem as planícies de inundação e os baixos terraços que foram eliminados da paisagem fluvial dos rios paulistanos. Depois de 30 anos, podemos afirmar que o diagnóstico de Seabra se mantém.

\section{Considerações finais}

Foram identificados três períodos de apropriação urbana da planície: (1) até a década de 1930, quando o sistema fluvial era integrado à cidade como fonte de recursos naturais e áreas 
de recreação, (2) da década de 1930 à de 1990, quando a urbanização se expandiu pelo sistema fluvial, com grandes obras de engenharia para geração de energia e controle de cheias, e (3) da década de 1990 até os dias atuais, marcado por um processo de reurbanização da área, com a construção de altos edifícios e grandes modificações no subsolo.

Ao contrário do que pode parecer, a percepção da importância da preservação das planícies de inundação não é recente. Em 1926, Saturnino Brito já alertava para a necessidade de se preservarem setores das planícies de inundação para controlar enchentes. Projetos mais recentes, das décadas de 1980 e 1990, também propuseram grandes intervenções nas margens dos rios paulistanos para recuperar, ao menos em parte, as funções hidrológicas perdidas pela supressão das planícies de inundação.

No entanto, a maior parte dos instrumentos de planejamento urbano não leva em conta essas referências e esses projetos. Exemplo disso é a mais recente revisão do Plano Diretor Estratégico do município de São Paulo, aprovada em julho de 2014, que inclui a maior parte das planícies fluviais paulistanas urbanizadas, bem como os raros remanescentes, em zonas de adensamento e aumento do potencial construtivo, denominada "macroárea de estruturação metropolitana" (Projeto de Lei n. 688/2013) (São Paulo, [2013]).

As mudanças feitas no sistema fluvial ao longo dos últimos 100 anos foram tão grandes e intensas, que qualquer projeto eficaz de controle de enchentes, ou mesmo de recuperação ambiental, demandará uma igualmente grande e intensa intervenção na área, bem como uma significativa mudança no uso da terra às margens do canal e nas áreas planas e baixas da antiga planície de inundação.

Os projetos que preveem a recuperação das funções hidrológicas e ecológicas perdidas existem e propõem uma mudança radical da lógica no uso e apropriação das planícies fluviais. Mas mudar uma lógica tão enraizada é um grande desafio: exige grande esforço político e mobilização social. Esforço proporcional à intensidade das intervenções ocorridas no sistema ao longo da urbanização.

\section{Referências}

AB'SABER, A. N. Geomorfologia do sítio urbano de São Paulo. Cotia, SP: Ateliê, 2007[1957].

AB'SABER, A. N. A planície do Tietê no planalto paulistano. Geomorfologia, São Paulo, V. 57, p. 1-24, 1978.

\section{ANGELI, P. A. L. As operações urbanas consorciadas como instrumento de pla-} nejamento urbano: estudo de caso na cidade de São Paulo. Dissertação (Mestrado em Urbanismo) - Centro de Ciências Exatas, Ambientais e de Tecnologias, Pontifícia Universidade Católica, Campinas, 2011.

BERGES, B. Geomorfologia urbana histórica à análise das inundações na Bacia Hidrográfica do Córrego da Mooca - São Paulo-SP. Dissertação (Mestrado em Geografia Física) - Faculdade de Filosofia, Letras e Ciências Humanas, Universidade 
de São Paulo, São Paulo, 2013. Disponível em: http://www.teses.usp.br/teses/disponiveis/8/8135/tde-17122013-125259/pt-br.php. Acesso em: 2 nov. 2017.

\section{BLANES, L. Análise dos biótopos da Bacia Hidrográfica do Córrego Águas}

Espraiadas-São Paulo-SP. Dissertação (Mestrado em Geografia Física) - Faculdade de Filosofia, Letras e Ciências Humanas, Universidade de São Paulo, São Paulo, 2006.

BRIDGE, J. S. Rivers and floodplains: forms, processes, and sedimentary record. Oxford: Blackwell Science, 2003.

BRITO, F. S. R. Melhoramentos do rio Tietê em São Paulo. Relatório. São Paulo: Seção de obras d'O Estado de S.Paulo. São Paulo, 1926.

CHRISTOFOLETTI, A. Geomorfologia fluvial. São Paulo: Edgar Blücher, 1981.

CUSTÓDIO, V. A persistência das inundações na Grande São Paulo. Tese (Doutorado em Geografia Humana) - Faculdade de Filosofia, Letras e Ciências Humanas, Universidade de São Paulo, São Paulo, 2002.

DAEE. DEPARTAMENTO DE ÁGUAS E ENERGIA ELÉTRICA. Disponível em: http:// www.daee.sp.gov.br/. Acesso em: 6 jun. 2020.

DINIZ, R. O.; FERRARI, S. M. A Billings e o Projeto Serra. História E Energia, São Paulo: Dep. de Patrimônio Histórico da Eletropaulo, v. 5, p. 22-25, 1995.

DOUGLAS, I. The Urban Environment. London: Edward Arnold, 1983.

EMAE. EMPRESA METROPOLITANA DE ÁGUAS E ENERGIA. Controle de cheias do canal Pinheiros. Apresentação de slides arquivada no site do Instituto de Engenharia. São Paulo. 2009. Disponível em: http://ie.org.br/site/ieadm/arquivos/arqnot2650.pdf. Acesso em: 5 jul. 2017.

EMAE. EMPRESA METROPOliTANA DE ÁGUAS E ENERGIA. Sistema Hidráulico.

Disponível em: http://www.emae.com.br/conteudo.asp?id=Sistema-Hidraulico. Acesso em: 7 jul. 2017.

ENVIRONMENT AGENCY. Irwell Catchment Flood Management Plan. Final Report 2008, managing flood risk. London: Environment Agency (United Kingdom), 2008.

FIX, M. A. Uma ponte para a especulação: ou a arte da renda na montagem de uma "cidade global". Caderno CRH, Salvador, v. 22, n. 55, p. 41-64, 2009. doi: https://doi. org/10.1590/S0103-49792009000100003.

FIX, M. A. São Paulo cidade global: fundamentos financeiros de uma miragem. São Paulo: Boitempo, 2007.

FIX, M. A. Fórmula mágica da parceria público-privada: operações urbanas em São Paulo. In:

Urbanismo: Dossiê São Paulo, Rio de Janeiro, Campinas. Campinas: PUC-Camp/ Prourb, 2004. p. 185-198. 
FUSP. FUNDAÇÃO DE APOIO À UNIVERSIDADE DE SÃO PAULO. Plano da Bacia Hidrográfica do Alto Tietê. Relatório Final. São Paulo: Comitê da Bacia Hidrográfica do Alto Tietê, 2009. $4 \mathrm{v}$.

GALLO, R.; GERARQUE, E. Condomínios descartam água de lençol freático na rua. Folha de S.Paulo, São Paulo, 8 abr. 2012. Disponível em: http://wwwl.folha.uol.com.br/ cotidiano/2012/08/1130166-condominios-descartam-agua-de-lencol-freatico-na-rua. shtml. Acesso em: 10 jun. 2017.

GREGORY, K. J. River channels. In: GREGORY, K. J.; WALLING, D. E. Human activity and environmental processes. Chichester/New York: Wiley, 1987. p. 207-235.

HEPNER, A. Desenho urbano, capital e ideologia em São Paulo: centralidade e forma urbana na marginal do rio Pinheiros. Dissertação (Mestrado em Arquitetura e Urbanismo) - Faculdade de Arquitetura e Urbanismo, Universidade de São Paulo, São Paulo, 2010.

HOCKIN, D. L. Channelization: some engineering aspects. The Geographical Journal, v. 151, n. 1, p. 54-57, 1985. doi: https://doi.org/10.2307/633278.

HOCKIN, D. L.; WHITTLE, I. R.; BAILEY, R. A. Managing and engineering rivers for the benefit of man. Water and Environment Journal, v. 2, n. 2, p. 151-158, 1978. doi. https://doi.org/10.1111/j.1747-6593.1988.tb01265.x.

$\mathrm{KAYO}, \mathrm{A}$. Impactos gerados pela ocupação no leito antigo do rio Pinheiros em áreas de operações urbanas consorciadas Faria Lima e Águas Espraiadas. Dissertação (Mestrado em Habitação, Planejamento e Tecnologia) - Instituto de Pesquisas Tecnológicas do Estado de São Paulo, São Paulo, 2013.

LEOPOLD, L. B.; WOLMAN, M. G.; MILLER, J. P. Fluvial processes in Geomorphology. San Francisco: W. F. Freeman, 1964.

LUZ, R. A. Mudanças geomorfológicas na planície fluvial do rio Pinheiros, São Paulo (SP), ao longo do processo de urbanização. Tese (Doutorado em Geografia Física) - Faculdade de Filosofia, Letras e Ciências Humanas, Universidade de São Paulo, São Paulo, 2014.

LUZ, R. A.; RODRIGUES, C. Anthropogenic changes in urbanised hydromorphological systems in a humid tropical environment: River Pinheiros, São Paulo, Brazil. Zeitschrift für Geomorphologie, v. 59, n. 2, p. 109-135, 2015. Supplementary Issues. doi: https:// doi.org/10.1127/zfg_suppl/2015/S-59207.

LUZ, R. A.; RODRIGUES, C. Reconstituição geomorfológica de planícies fluviais urbanizadas: o caso do rio Pinheiros, São Paulo-SP. Revista Brasileira de Geomorfologia, v. 14, n. 1, p. 47-57, 2013. doi: http://dx.doi.org/10.20502/rbg.v.

MONTEIRO, P. R. São Paulo no centro das marginais: a imagem paulista refletida nos rios Pinheiros e Tietê. Tese (Doutorado em Design e Arquitetura) - Faculdade de Arquitetura e Urbanismo, Universidade de São Paulo, São Paulo, 2010. 
OSEKI, J. H. A fluvialidade do rio Pinheiros: um projeto de estudo. Revista do Programa de PósGraduação em Arquitetura e Urbanismo da FAUUSP, São Paulo, n. 8, p. 168-177, 2000.

PENA, D. Despoluir o Pinheiros, tarefa de gerações. Folha de S.Paulo, 20 mar. 2008. Disponível em: https://www.saopaulo.sp.gov.br/spnoticias/na-imprensa/despoluir-opinheiros-tarefa-de-geracoes/. Acesso em: 15 jun. 2020.

PONTES, J. A. O. V. Pinheiros: do rio ao canal. História E Energia, São Paulo: Dep. de Patrimônio Histórico da Eletropaulo, p. 15-29, 1995.

RODRIGUES, C. Sistemas geomorfológicos e o impacto da urbanização na metrópole de São Paulo. In: SIMPÓSIO NACIONAL DE GEOMORFOLOGIA, 6., 2006, Goiânia. Anais... Goiânia, 2006.

RODRIGUES, C. A urbanização da metrópole sob a perspectiva da geomorfologia: tributo a leituras geográficas. In: CARLOS, A. F. A.; OLIVEIRA, A. U. (Ed.). Geografias de São Paulo: representação e crise da metrópole. São Paulo: Contexto, 2004. p. 89-114.

RODRIGUES, C.; MOROZ-CACCIA GOUVEIA, I. C.; LUZ, R. A.; VENEZIANI, Y; SIMAS, I. T. H; SILVA, J. P. Antropoceno e mudanças geomorfológicas: sistemas fluviais no processo centenário de urbanização de São Paulo. Revista do Instituto Geológico, São Paulo, v. 40, n. 1, p. 105-123, 2019. doi 10.33958/revig.v40il.631.

SANTOS, A. L. Paisagem útil: o rio Tietê e a urbanização paulistana (1966-1986). Dissertação (Mestrado em Arquitetura e Urbanismo) - Instituto de Arquitetura e Urbanismo, Universidade de São Paulo, São Carlos, 2014.

SÃO PAULO (Município). Projeto de Revisão do Plano Diretor Estratégico. [2013]. Disponível em: http://gestaourbana.prefeitura.sp.gov.br/novo-plano-diretor-estrategico/. Acesso em: 5 jul. 2017.

SÃO PAULO (Município). Área urbanizada, segundo períodos de expansão Região Metropolitana de São Paulo. Município em Mapas. São Paulo: Sempla, 2007. (Série Pôster: Panorama.)

SCIFONI, S. Parque do Povo: um patrimônio do futebol de várzea em São Paulo. Anais do Museu Paulista, São Paulo, v. 21, n. 2, p. 125-151, 2013.

SEABRA, O. C. D. L. Enchentes em São Paulo: culpa da Light? História E Energia, São Paulo: Dep. de Patrimônio Histórico da Eletropaulo, p. 64-71, 1995.

SEABRA, O. C. D. L. Os meandros dos rios nos meandros do poder, Tietê e Pinheiros:

valorização dos rios e das várzeas na cidade de São Paulo. Tese (Doutorado em Geografia Humana) - Faculdade de Filosofia, Letras e Ciências Humanas, Universidade de São Paulo, São Paulo, 1987.

TRICART, J. Os tipos de leitos fluviais. Notícias Geomorfológicas, Campinas, v. 6, n. 11 , p. 41-49, 1966. 